\title{
The Value and Incentives of Option-based Compensation in Danish Listed Companies
}

\author{
Bechmann, Ken; Jørgensen, Peter Løchte
}

Document Version

Final published version

Publication date:

2003

License

CC BY-NC-ND

Citation for published version (APA):

Bechmann, K., \& Jørgensen, P. L. (2003). The Value and Incentives of Option-based Compensation in Danish Listed Companies. Institut for Finansiering, Copenhagen Business School. Working Papers / Department of Finance. Copenhagen Business School No. 2003-2

Link to publication in CBS Research Portal

\footnotetext{
General rights

Copyright and moral rights for the publications made accessible in the public portal are retained by the authors and/or other copyright owners and it is a condition of accessing publications that users recognise and abide by the legal requirements associated with these rights.

Take down policy

If you believe that this document breaches copyright please contact us (research.lib@cbs.dk) providing details, and we will remove access to the work immediately and investigate your claim.
}

Download date: 26. Apr. 2023 
WP 2003-2

The Value and Incentives of Option-based Compensation in Danish Listed Companies by Ken L. Bechmann \& Peter Løchte Jørgensen

\footnotetext{
INSTITUT FOR FINANSIERING, Handelshøjskolen i København Solbjerg Plads 3, 2000 Frederiksberg C tlf.: 38153615 fax: 38153600

DEPARTMENT OF FINANCE, Copenhagen Business School Solbjerg Plads 3, DK - 2000 Frederiksberg C, Denmark Phone (+45)38153615, Fax (+45)38153600

www.cbs.dk/departments/finance
} 


\section{The Value and Incentives of Option-based Compensation in Danish Listed Companies}

Ken L. Bechmann

Department of Finance

Copenhagen Business School

Solbjerg Plads 3

DK-2000 Frederiksberg

Phone: +4538152953

Fax: $\quad+4538153600$

email: kb.fi@.cbs.dk
Peter Løchte Jørgensen

Department of Management

University of Aarhus

University Park 322

DK-8000 Århus C

Phone: +45 89421544

Fax: $\quad+4586135132$

email: ecolochte@econ.au.dk

September 1, 2003

Key words: Option-based compensation, executive pay, disclosure requirements, valuation, incentives.

JEL Classification: G30; G13; J33.

\footnotetext{
${ }^{*}$ We gratefully acknowledge the excellent research assistance of Trine Hansen and Sanne Borgstrøm, as well as useful comments from two anonymous referees, Bjarne Florentsen, Ole Ø. Madsen, and Michael Møller. The paper has also benefited from discussions with participants at the 2002 Annual Meeting of the Danish Economic Society, the 2003 Annual Meeting of the Multinational Finance Society, and at seminars at the Department of Finance, Copenhagen Business School, the Danish Central Bank, and at the Danish Financial Supervisory Authority. Financial support from the University of Aarhus' Research Foundation (Grant \# F-2000-SAM-1-10) is also gratefully acknowledged.
} 


\title{
The Value and Incentives of Option-based Compensation in Danish Listed Companies
}

\begin{abstract}
Over the last decade the Danish corporate environment has experienced a significant increase in the use of option-based compensation (OBC). This and many other facts are documented in the present paper which provides the first insights into the characteristics of the option and warrant contracts issued by the complete sample of Danish companies listed on the Copenhagen Stock Exchange.

A newly constructed database containing all publicly available information on details of Danish $\mathrm{OBC}$ contracts allows us to present, for example, results regarding contract values at an aggregated as well as at firm, personnel group, and individual level. The paper also contains a section which discusses and presents evidence on the incentive effects provided by the option-based compensation contracts adopted by Danish listed companies.
\end{abstract}

Key words: Option-based compensation, executive pay, disclosure requirements, valuation, incentives.

JEL Classification: G30; G13; J33 


\section{Introduction}

The use of option-based compensation (OBC) has dramatically increased among the Danish corporations over the past few years for its usefulness as an instrument to align the interests of managing agents with those of shareholders (see e.g. Jensen and Meckling (1976), Holmstrom (1982), Holmstrom and Milgrom (1987)). The increased use of OBC has taken place during a period which has also seen a generally increased focus on the principles of good corporate governance and shareholder value based management. ${ }^{1}$ This article describes and interprets the development of OBC among Danish listed companies from 1995 - when executive and employee stock options were virtually unknown in Denmark - to the present.

The extensive use of $\mathrm{OBC}$ has caused considerable debate in the news media as well as in the political arena in Denmark as well as in many other countries - most notably the US and the UK. While proponents of $\mathrm{OBC}$ have vigorously advocated the benefits of this new form of compensation, critics have been raised over the excessively generous compensation schemes. However, evidence on the extent to which OBC has been used in Denmark remains undocumented. Although one can find a handful of questionnaire-based surveys in business magazines and in reports from consulting firms and investments banks, the information provided is often incomplete, poorly documented, and inaccessible for an international audience. ${ }^{2}$ The primary goal of the present article is to document the use of $\mathrm{OBC}$ and its development in Denmark.

The facts and data we present will not only serve to complete the picture and form a more solid foundation for a sound debate of the pros and cons of OBC. It will also enable us to analyze many different aspects of $\mathrm{OBC}$ for example in relation to valuation and incentive effects.

The valuation of employee stock options is important for a number of reasons. First of all, the issuer (the firm) and the recipient (employee/executive) of this type of compensation have a natural interest in knowing the value of the options. The firm must assess and report the costs associated with the option grant, and the employee will wish to know the cash equivalent of his/her compensation package. In addition, a valuation scheme - a model - is essential for both parties' evaluation of the option value sensitivities which are directly related to the implied incentive effects. The revenue service, auditors, and investors are other parties with an interest in knowing the value of a firm's OBC plan. Finally, at the

\footnotetext{
${ }^{1}$ In March 2001 the Danish government commissioned a report on proposals for recommendations regarding good corporate governance in Denmark. The report was published in December 2001 and is downloadable (partly in English) from www.corporategovernance.dk.

${ }^{2}$ Details on these Danish publications are available from the authors. Some earlier results from our data have been published in Danish as well (see Bechmann and Jørgensen (2003)).
} 
macro level various statistical bureaus will need option values in order to analyze the tendencies in wage development and aggregated salary data.

The rest of the article is organized as follows: In section 2 we briefly discuss Danish disclosure rules, explain the data collection process, and present summary statistics for our data set. We illustrate the development over time in the number of firms using $\mathrm{OBC}$ and determine the distribution between plain vanilla call options, warrants and other option types. Furthermore, we document how the use of OBC varies with the type of the issuing firm, and we present statistics regarding the exercise provisions and time to maturity of the issued options. In subsequent sections we turn our attention to the valuation of the option contracts. The Black-Scholes model (Black and Scholes (1973)) is adapted for valuation in section 3 , and in section 4 we present a variety of results and summary statistics from implementing this model using input variables from our data set. We report the development in total option value over time and present results on absolute values of option programs as well as values relative to the market capitalization of the individual firms. We also describe how the issued options are distributed among various groups of employees, and we compare the development in $\mathrm{OBC}$ to the development in traditional salaries during the period in question. Section 5 briefly discusses the provision of incentives via $\mathrm{OBC}$ and reports results on key characteristics such as option deltas and moneyness for the contracts in our data set. The final section concludes.

\section{Disclosure Rules, Data Collection, and Descriptive Results}

The basis of this article is a newly collected data set comprised of the complete publicly available information on option-based compensation in all of the 200-250 listed companies in Denmark. This data set was constructed via an analysis of financial statements, annual reports, and company announcements involving information on option-based compensation from the time of issue of the first $\mathrm{OBC}$ contract by a listed firm in Denmark in 1995 until July 2003. Details on OBC are available from these sources as a consequence of Danish legislation and the Rules Governing Securities Listing on the Copenhagen Stock Exchange (the Rules). Specifically, according to the Danish Securities Trading Act (Clause 27, section 1), listed firms are required to "immediately disclose important information concerning the firm which may be considered relevant for pricing its stock". The Rules are periodically updated, and in the two most recent issues it has been emphasized that decisions and details regarding option compensation are to be considered as such "important information". The first specification stating that option details had to be reported came in the previous issue of the Rules which was effective as of October 1, 1999. This version of the Rules explicitly required firms to disclose information on option type (e.g. warrant or option), number of options and their date of issue, time to maturity, strike price, and exercise provisions. Firms 
were also required to disclose information on the distribution of the options among three recipient groups (directors, executives, and employees). In the most recent issue of the Rules, which was effective as of January 1, 2002, the disclosure requirements were further clarified and expanded. For instance firms must now distinguish between managers and other employees in their reporting on recipient groups. In addition firms should report their own assessment of the value of the total option liability. ${ }^{3}$ Disclosures should take the form of an immediate company announcement and should be repeated in the annual report.

In order to build a database with all this information we have searched the CSE's electronic StockWise database containing all company announcements dating back to $1995 .{ }^{4}$ Annual reports containing the financial statements and associated notes were obtained directly from the listed companies.

In the present section we provide some main descriptive statistics regarding the data set which we have compiled from the above-mentioned sources. We emphasize that the data set contains all publicly available information regarding the OBC plans of all CSE-listed companies. We shall return to discussing some firms failure to disclose information in accordance with the Rules.

First we will consider the development over time in the total number as well as in various proportions of listed firms which have implemented some type of option compensation. The year 1995 is the first for which we have registered an option grant to executives and/or employees in a Danish listed firm.

Table 1 clearly shows that both the absolute and the relative number of firms using option compensation have increased significantly from the mid 1990s to the present. However, figures from recent years suggest that a saturation point have been reached. Furthermore, the table indicates that option-based compensation is more common in larger firms. As figures from 2001-2003 show, approximately half of all listed firms have issued options compared to about two thirds of the top 100 firms. The proportion of KFX firms using options in compensation plans has now reached $80 \%$. A noticeable result, which is not reported in the table, concerns the use of option-based compensation by firms entering the CSE's technology-based KVX index. During the period 2000-2002 all of the firms in this index used options as a means of compensation. ${ }^{5}$

\footnotetext{
${ }^{3}$ About $48 \%$ of OBC granting firms comply with this new disclosure requirement in annual reports for 2002. Most of these firms state that the Black-Scholes formula has been used to estimate the value/cost of the issued options or warrants. Casual inference on this rather small subset of the data suggest that the firms' self-reported option values are highly correlated with but also systematically smaller than the option values calculated by the authors. This is obviously a subject worthy of further research as more data becomes available.

${ }_{5}^{4}$ Access to the StockWise database can be obtained via the CSE homepage, www.cse.dk.

${ }^{5}$ The KVX index was formed on September 1, 2000, and represented growth-firms primarily in the sectors of information technology, telecommunication, medicine, and biotechnology. During its lifetime the index typically comprised 10-15 firms. Having lost almost 80\% of its initial value the index was shut down on Sept. $1^{\text {st }}, 2003$.
} 
Table 1: Development in number and proportion of firms using option compensation in Denmark since 1995.

\begin{tabular}{|l|c|cc|c|c|}
\hline Year & $\begin{array}{c}\text { Total number } \\
\text { of firms listed } \\
\text { on the CSE }\end{array}$ & \multicolumn{2}{|c|}{$\begin{array}{c}\text { Number of firms } \\
\text { with options } \\
\text { (percentage) }\end{array}$} & $\begin{array}{c}\text { Percentage of } \\
\text { top-100 firms } \\
\text { with options }\end{array}$ & $\begin{array}{c}\text { Percentage of } \\
\text { KFX-firms with } \\
\text { options }\end{array}$ \\
\hline $1995^{4)}$ & 252 & 5 & $(2 \%)$ & $4 \%$ & $0 \%$ \\
\hline 1996 & 249 & 6 & $(3 \%)$ & $5 \%$ & $0 \%$ \\
\hline 1997 & 249 & 17 & $(7 \%)$ & $14 \%$ & $5 \%$ \\
\hline 1998 & 254 & 46 & $(18 \%)$ & $29 \%$ & $38 \%$ \\
\hline 1999 & 242 & 66 & $(27 \%)$ & $43 \%$ & $55 \%$ \\
\hline 2000 & 235 & 97 & $(41 \%)$ & $59 \%$ & $68 \%$ \\
\hline 2001 & 219 & 107 & $(49 \%)$ & $63 \%$ & $74 \%$ \\
\hline 2002 & 201 & 94 & $(47 \%)$ & $64 \%$ & $80 \%$ \\
\hline $2003^{5)}$ & 196 & 94 & $(48 \%)$ & $64 \%$ & $80 \%$ \\
\hline
\end{tabular}

Notes to Table 1:

1) Reported numbers are for the end of the year and do not include mutual funds.

2) The 100 largest firms measured by total market value of outstanding stocks at the end of the year.

3) The KFX is the main official index of the Copenhagen Stock Exchange. The index is comprised of the 20 most actively traded stocks in terms of market value. Due to the biannual revision of the index, more than 20 stocks may have been index members during a year.

4) Data from 1995 were extracted from 1995 company announcements, 1995 annual reports and for firms with non-calendar financial years, the figures from 1995/1996 statements were used. The same applies to data for the following years.

5) Data for 2003 are as of the end of July 2003 and are updated solely based on company announcements, as annual reports for 2003 are not available at this writing.

The data set contains examples of OBC plans in all types of firms. As seen in Table 2, option-based compensation is not particularly popular among financial firms of which only $24 \%$ have implemented this type of compensation. Quite the opposite conclusion applies for firms in the IT and telecommunication sectors where all firms use option compensation. Firms in the health care business are also relatively frequent users of OBC. ${ }^{6}$

\footnotetext{
${ }^{6}$ Table 2 and some later tables and figures showing cross-sectional results are based on data from 2002. Results for earlier years are similar in most cases. The exceptions will be commented as we proceed.
} 
Table 2. Use of option compensation among different types of issuers - 2002.

\begin{tabular}{|l|c|c|c|}
\hline Business sector of issuing firm & $\begin{array}{c}\text { Number of firms } \\
\text { with options }\end{array}$ & $\begin{array}{c}\text { Number of } \\
\text { firms in this } \\
\text { category }\end{array}$ & $\begin{array}{c}\text { Percentage } \\
\text { using options }\end{array}$ \\
\hline Materials & 5 & 7 & $71 \%$ \\
\hline Industrials & 29 & 56 & $52 \%$ \\
\hline Consumer Discretion & 11 & 27 & $41 \%$ \\
\hline Consumer Staples & 7 & 13 & $54 \%$ \\
\hline Health Care & 11 & 13 & $85 \%$ \\
\hline Financials & 17 & 70 & $24 \%$ \\
\hline IT & 12 & 12 & $100 \%$ \\
\hline Telecommunications & 1 & 1 & $100 \%$ \\
\hline Utilities & 1 & 2 & $50 \%$ \\
\hline Total & 94 & 201 & \\
\hline
\end{tabular}

There may be several reasons why relatively few firms in the financial sector use options. One possible explanation is the presence of the Financial Supervisory Authority (FSA) which monitors a wide selection of variables including directors' and executives' salaries. One could imagine that a general aversion towards drawing too much attention from the FSA might cause some reservation from using this type of compensation. Another possible explanation is that owners find it less relevant to encourage management in the financial sector firms to accept a suitably high risk as firms in this sector are already highly levered as it is. On the other hand the widespread use of OBC in the IT and telecom sectors is not surprising. Many of these firms are notoriously cash-constrained and perhaps also particularly vulnerable to key employees leaving the firm. Option compensation may be a way to alleviate such problems. Some would also argue that typical employees in such firms are risk-taking talented individuals who have a higher than average taste for at least partial compensation in the form of options.

There are several different ways of issuing option-based compensation. The possibilities vary from regular or plain vanilla call options and warrants over convertible bonds to more specialized constructions involving phantom stock and very complex incentive schemes and option constructions. ${ }^{7}$ The common characteristic of all these instruments is that they imply an economic reward to the holder when the price of the firm's stock increases. They will therefore imply an incentive for the recipient to concentrate his efforts to the benefit of the firm's profitability. In this way the incentives of stock holders and option

\footnotetext{
${ }^{7}$ Convertible bonds are bonds which under certain conditions give the lender (e.g. an executive) an option to convert the loan into a specific number of shares.
} 
recipients should be better aligned. The difference between the two most common OBC instruments options and warrants - is that new shares are issued when warrants are exercised whereas existing shares must be delivered following the exercise of options. Warrants may thus be advantageous for cash/liquidity constrained firms but the benefit comes with the cost of changing the firms capital structure and a dilution effect which may or may not be significant depending on the ratio of optionable shares to old/existing shares. Other differences in the design of $\mathrm{OBC}$ stem from attempts to fine tune the incentives created. However, a detailed analysis of the more exotic constructions is beyond the scope of this article. ${ }^{8}$ Figure 1 illustrates the distribution of different option types in Danish listed firms in 2002.

Figure 1. Use of various types of incentive instruments -2002 .

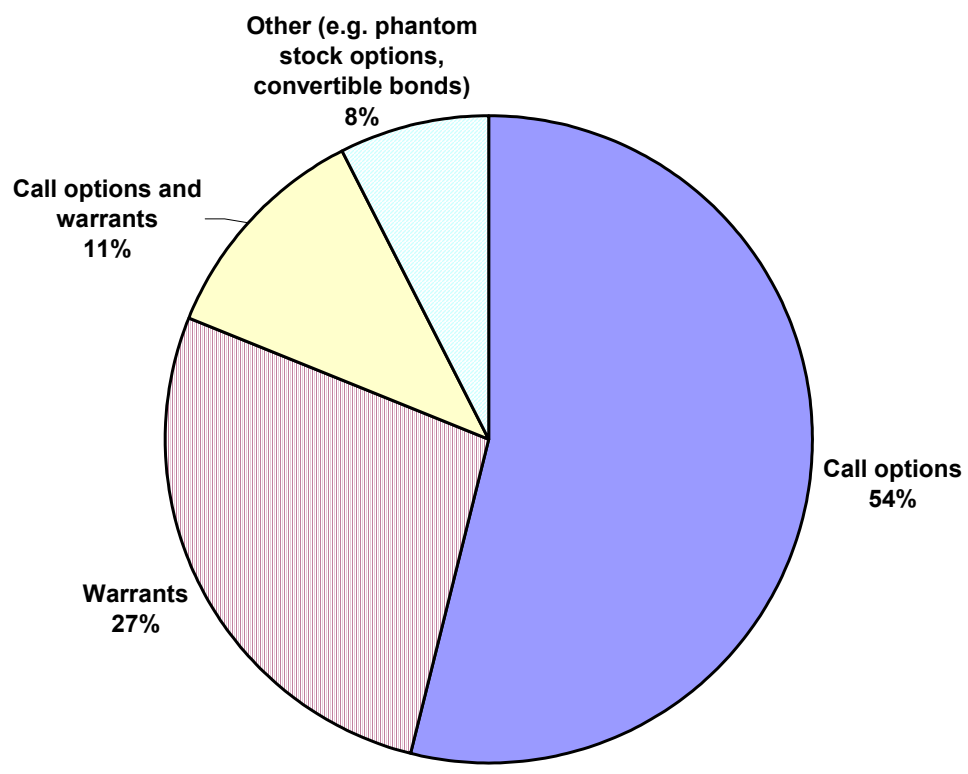

As seen in Figure 1, 54\% of the programs are regular call options, which thus constitute the most frequently used instrument in option compensation. Pure warrant programs are seen in $27 \%$ of the cases whereas $11 \%$ of the programs combine call options and warrants. Finally, $8 \%$ of the programs use other instruments such as phantom stock or convertible bonds. The relative importance of these other instruments has declined over the past few years and now firms tend to use standard call options or warrants. It has also become more common to mix options and warrants in the incentive schemes. That options are relatively more popular than warrants may be explained by the fact that options can be granted without the approval of the annual shareholders' meeting.

\footnotetext{
${ }^{8}$ Our data set contains examples of extremely exotic option constructions such as reload options, indexed options, and knock-in options. See e.g. Hull (2003) for terminology and a more detailed description. The data set even contains examples of put options (!) and options with strike prices that decrease over time.
} 
In relation to the categorization in Figure 1 it should be emphasized that although a specific program is characterized as consisting solely of call options it will typically still be rather complex. There are several explanations for this. First, a program often consists of a number of option series with different times to maturity, exercise prices and distributions among executives and other groups of employees in the firm. Second, one or more exotic features may characterize a specific option series. For instance, the strike price can be increasing over time or defined relative to a certain index. Further, exercise may only be allowed in certain time "windows" or at a series of specific dates. Finally, an option may come with other forms of conditions, stating for example that the recipient must be employed at the time of exercise. ${ }^{9}$ As for exercise provisions and exercise price constructions we provide Figure 2 which categorizes the 83 OBC programs for which we have adequate information as of the end of 2002.

Figure 2. Exercise provisions and strike price constructions of OBC programs in Danish listed companies -2002 .

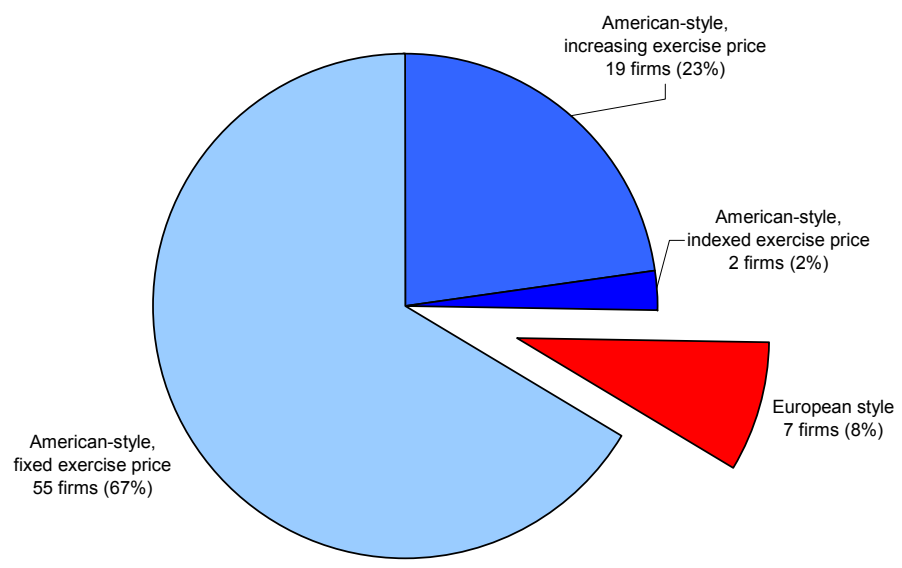

In connection with Figure 2 it should be noted that some firms have mixed types of OBC programs, i.e. they may have issued European- as well as American-style option series. American-style options can be exercised prior to their maturity date whereas European-style options can be exercised only at the maturity date. We have categorized firms according to their most advanced issue with American-style being more advanced than European-style and indexed or increasing exercise price being more advanced than fixed exercise price.

\footnotetext{
${ }^{9}$ Forfeiture clauses to employee options are customary in the US. Similar clauses have been included in Danish option programs, but in 2001 and again in 2003 The Danish Maritime and Commercial Court ruled such clauses in conflict with general terms in the so-called Salaried Employee Act. The verdicts have been appealed and the Danish Government has announced its intention to consider appropriate adjustments to the legislation.
} 
Figure 2 shows that $\mathrm{OBC}$ programs which include American-style options are the preferred choice of Danish listed firms. This is not surprising as American-style options are more flexible and have higher deltas. An option's delta is the first derivative of its value with respect to the underlying stock price and is therefore a measure of the strength of the incentive created by the option, cf. also later. The proportion of programs with increasing or indexed exercise price has increased in recent years and is much higher than in the US where virtually all options in corporate incentive schemes are granted with fixed exercise prices (Murphy (1999)). The development towards options with increasing or indexed exercise prices is probably a reaction to the growing critique of the overly advantageous terms implied by the fixed exercise price construction, see e.g. Rappaport (1999).

Table 3 below presents statistics on the option series' time to maturity at issuance. It is seen that the typical time to maturity for Danish OBC programs is around five years which is considerably shorter than that observed in for example the US. Murphy (1999) reports a typical time to maturity of ten years in US contracts. The fact that OBC programs in Danish firms are relatively short-lived is further documented by the fact that 13 of 94 firms have issued options with a time to maturity of three years or less, whereas only 7 firms have issued options with a time to maturity above 8 years. The difference between Danish and US OBC programs' time to maturity is puzzling at first, but may be at least partly explained by the fact that although Danish firms issue shorter individual option series, they often simultaneously commit to future periodic issues of new options. The implication of such commitments will be a longer effective duration of the incentive schemes than what can be inferred from individual option series' time to maturity. This seemingly "Danish" preference for creating loyalty incentives with revolving option grants instead of longer-term contracts may have been influenced by the court rulings mentioned in footnote 9 .

Table 3. Time to maturity at issuance for OBC programs in Danish listed companies -2002.

\begin{tabular}{|l|c|c|c|c|}
\hline & Average & Median & Minimum & Maximum \\
\hline Time to maturity (years) & 5.1 & 5 & 1 & 20 \\
\hline
\end{tabular}

\begin{tabular}{|l|c|c|c|c|}
\hline Time to maturity (years) & $<3$ & $3-5$ & $5-8$ & $>8$ \\
\hline Number of firms & 13 & 48 & 26 & 7 \\
\hline
\end{tabular}




\section{Option Program Valuation}

Following the presentation of some of the main characteristics of our data set in the previous section, we will now turn our attention to the valuation of the programs. The issue of valuation is important to several parties. Not only the issuer (firm) and recipient (employee) have a keen interest in knowing the option value but also outside parties such as revenue services, potential investors, auditors, and salary statisticians.

When valuing option programs one must select a particular model and the results are thus influenced not only by the model choice, but also by the parameter choices and/or parameter estimates used. The literature on option pricing is extensive, and numerous models have been proposed and analyzed. We will not try to present an overview of the many results and recommendations in this literature (see instead Carpenter (1998), Rubinstein (1995), and Murphy (1999)), but we will merely emphasize one of the most important conclusions emerging from this literature, which has gained a wide consensus: The value of options issued to employees in a firm depends on whether the option is considered from the issuer's (firm's) perspective or that of the recipient (employee).

If we consider the options from the perspective of the firm, standard option pricing results like the BlackScholes formula (Black and Scholes (1973)) can be used in a more or less straightforward fashion for determining the value of standard European call options under simple market assumptions. This value of the options is clearly relevant for cost accounting purposes. The firm should be regarded as a free market player and as the firm's financial report should reflect the perspective of the firm and its shareholders and not the entities with which it contracts, the cost of the stock options is the cash foregone by granting the options to employees rather than selling them to external investors. The market value of the options is determined by the cost of hedging the option through dynamic trading of the firm's stock. This hedgebased derivation of the option value is the most fundamental assumption underlying the Black-Scholes formula.

The situation is somewhat different if we consider the stock options from the employee's perspective. As the main purpose of option compensation is to expose the executive's personal wealth to changes in the firm's stock value, the employee is not permitted to sell or hedge his options. ${ }^{10}$ With these restrictions, however, the theoretical foundation for the Black-Scholes pricing model erodes and alternative solutions must be sought. The literature on this subject suggests a number of alternative pricing methods. These are

\footnotetext{
${ }^{10}$ Whether these restrictions are actually binding in practice has been questioned. See e.g. the discussions in Bebchuk, Fried, and Walker (2002) and Jørgensen (2002).
} 
typically based on calculations of expected utility and certainty equivalents (see e.g. Lambert, Larcker and Verrecchia (1991)).

In this article we choose the firm's perspective. In other words, we focus on the firm's cost of the option issue, which appears to be the most interesting quantitative measure in most contexts. Moreover, it follows from the discussion above that taking this perspective justifies the application of standard results from option pricing theory such as the Black-Scholes' formula and its modified versions. ${ }^{11}$

The implementation of Black-Scholes formula in relation to a particular firm's option program requires fairly detailed information on the option details and particularly information on changes in the program since its inception. These changes will typically stem from annulment or exercise of previously issued options. Problems with the quality of disclosed information is discussed next.

\subsection{Data Quality and Disclosure Willingness}

The data collection process for this study has not been without obstacles. ${ }^{12}$ Despite very clear legislation and recent further clarification of the disclosure requirements of the CSE, some firms fail to provide adequate information on their OBC plans. This constitutes an impediment to our valuation analysis as we will be limited to including only the firms that provide adequate information in order for a valuation to make sense. For the year 2002, for example, 12 of the 94 firms using option compensation must be excluded from further valuation analysis on account of incomplete or inaccurate reporting. In order to illustrate these problems further we have classified the $\mathrm{OBC}$ granting firms in three categories according to the quality of the information provided. The categories are labeled "satisfactory", "inadequate", and "vapid". The classification is admittedly somewhat subjective but otherwise rests on the following criteria. The "satisfactory" category represents firms whose disclosure policy follows the Rules of the CSE quite closely, thereby enabling straightforward calculation of the market value of its issued options. We have assigned the predicate "inadequate" to firms which have released information on contract details which is not satisfactorily accurate to allow for a very precise determination of option value. Lack of precision in details regarding e.g. time to maturity, exercise price, recipient groups and/or date of issue will classify the information as inadequate. A firm's disclosure policy is classified as "vapid" if crucial information like for instance the number of options, strike price or time to maturity is omitted entirely. When such crucial information is lacking, any kind of valuation will be pure speculation. In the following analyses of option values we have thus not included firms which provide vapid information.

\footnotetext{
${ }^{11}$ In the use of utility-function based valuation methods, it is necessary to include several other agent-specific assumptions such as risk aversion, additional wealth, and general portfolio composition. Option values are often highly sensitive to these assumptions. See e.g. Lambert, Larcker, and Verrecchia (1991) and Rubinstein (1995).

${ }^{12}$ See also the detailed discussion in Bechmann and Jørgensen (2002).
} 
Figure 3 provides an illustration of the development in the proportions of firms releasing satisfactory, inadequate and vapid information during the period 1995-2002. Until recently less than $20 \%$ of firms using option-based compensation provided satisfactory information on their incentive programs. In 2002 a significant improvement occurred with $39 \%$ of OBC granting firms categorized as satisfactory. This sudden increase in the quality of information on $\mathrm{OBC}$ may have been a reaction to a severe criticism on Danish firms' OBC information policy which was raised in early 2002, see e.g. Bechmann and Jørgensen (2002). From Figure 3 it is also safe to conclude that although the proportion of firms delivering vapid information has decreased, the proportion of firms providing inadequate information is still alarming. About half of all OBC granting firms are still in this group. Moreover, quite a few firms are moving in the wrong direction with regard to their ability to provide information on incentive programs in accordance with the Rules. For example, of the 18 firms belonging to the "satisfactory" category in 2000, seven lost that status in 2001 and became "inadequate". ${ }^{13}$ Most of these are firms whose option programs have become so extensive and complex that providing complete detailed information may have been considered an overwhelming and too resource-demanding task. ${ }^{14}$

Figure 3: Development in the proportion of firms in various disclosure quality classes.

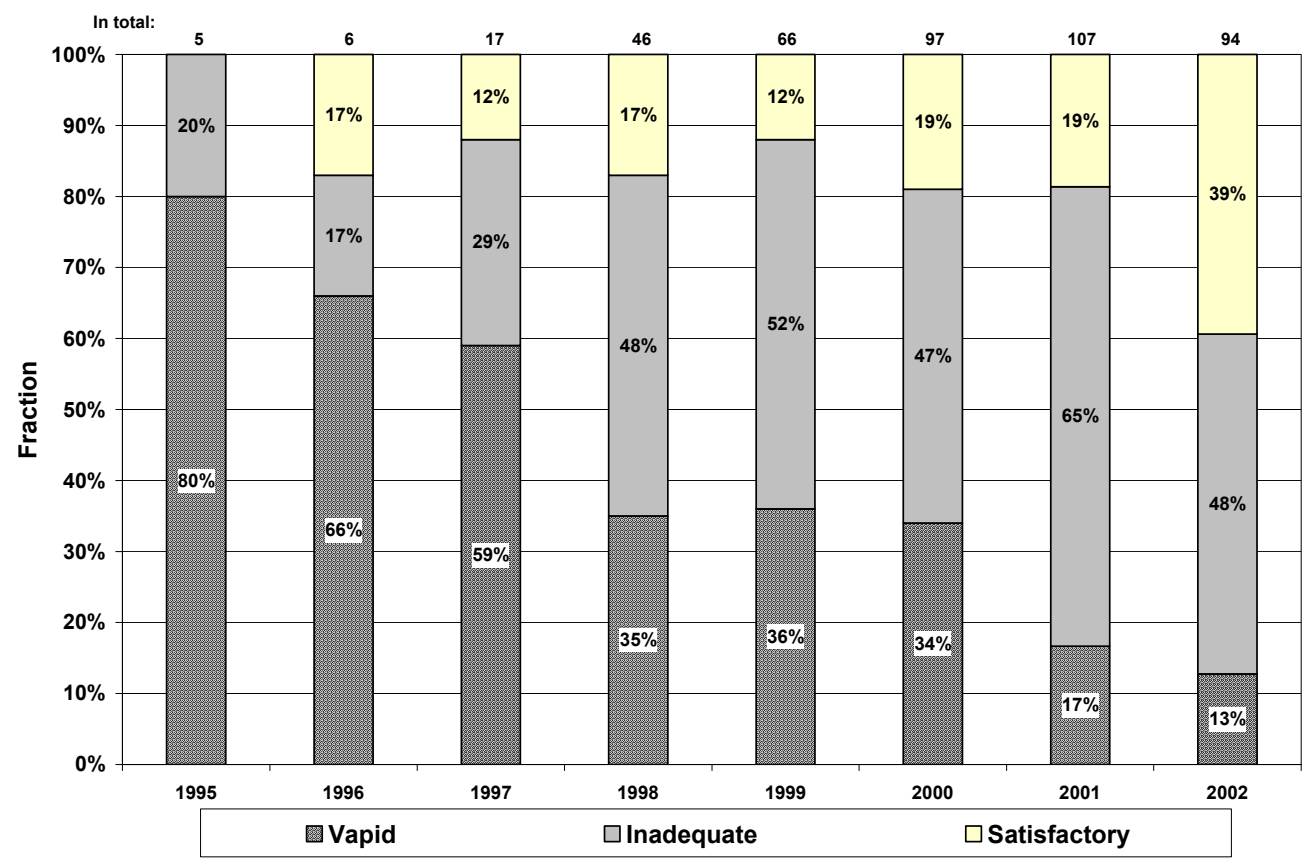

\footnotetext{
${ }^{13}$ Three of these seven firms regained the "satisfactory" predicate in 2002.

${ }^{14}$ Genmab is an example of a firm with an extensive option program. The description of the program takes up six pages of the annual report and is still not adequate since the distribution of individual option series to executives and other groups of employees in the firm is not documented in the disclosure documents.
} 
Before turning to the presentation of our valuation results, it is important to note that there are a few fairly significant programs which it has not been possible to value. One example is the NASDAQ cross-listed firm Olicom, which has more than 2 million outstanding options but fails to provide information on all options' maturity dates. Another important observation is that the lack of adequate information from a firm in a given year is sometimes remedied by disclosures in later years. In other words, we sometimes find more recent information to be more complete - also with respect to previous years' option issues. The new information can thus sometimes be used to decipher earlier programs. We are therefore quite confident that the development over time of the option values that we establish provides a fairly accurate overall picture of the development in program values.

\subsection{Some Notes on the Implementation of the Black-Scholes Model}

We have used Black-Scholes' (1973) formula to value the individual option series of the incentive programs. Each firm's option program usually consists of more than one issuance, as new portions are typically issued periodically, e.g. at strike price and time to maturity differing from previously issued series. The detailed assumptions underlying the Black-Scholes formula can be found in any modern textbook on finance theory so they will not be repeated here. The evaluation of the Black-Scholes formula for the value of a call option requires six input variables: The value of the underlying stock, dividend rate, exercise price, time to maturity, interest rate, and volatility. As we are only investigating listed firms, stock prices and historical dividend rates are easily obtainable from various databases. The exercise price and time to maturity are contract characteristics and should ideally be available from company announcements and annual reports, provided that firms comply with disclosure requirements. ${ }^{15}$ On each valuation date we use a concurrent five-year government bond yield as "the interest rate". The five-year horizon roughly matches the average maturity of the options, cf. Table 3 . The final parameter is the stock price volatility. This is estimated using daily historical price data spanning one year back from the valuation date. This is a standard procedure which is described for instance by Hull (2003).

It should also be noted that not all issued options are plain vanilla European call options and thus not in exact correspondence with the derivative asset type priced by the Black-Scholes model. ${ }^{16}$ There may be a touch of American option in an option series, or the exercise price may be increasing over time (see Figure 2). In some cases we have attempted to adjust the formula according to these specific conditions,

\footnotetext{
${ }^{15}$ Some firms adjust the number of optionable stocks or the exercise price of issued options in connection with dividend payments. In those cases we simply implement the Black-Scholes formula using a dividend rate of zero assuming thus that the dividend protection is "perfect". To the extent that some firms make similar adjustments but do not report this, our calculated option values will underestimate the true value. See Merton (1976) for a series of dividend protection theorems.

${ }^{16}$ Warrants are priced using a procedure similar to the one described in Hull (2003). The procedure builds on the Black-Scholes formula but takes the dilution effect of warrants into account.
} 
but other than that we have worked from a pragmatic point of view and judged the highly increased complexity inherent in various extensions of the Black-Scholes formula to be unjustified when compared to the added benefits in terms of valuation precision. This presents a possible source of error in the valuation results presented in the next section, but we regard it as fairly insignificant.

\section{Valuation Results}

The current section presents a wide variety of valuation results for the $\mathrm{OBC}$ contracts which have been issued by Danish listed firms since 1995 onwards. We start out by presenting Table 4 which lists some aggregated results on the development of the total value of the programs we have been able to value. ${ }^{17}$

Table 4. Development in the total value of option-based compensation programs in Danish listed firms, 1995-2002.

\begin{tabular}{|c|c|c|c|c|c|}
\hline & $\begin{array}{l}\text { Number of firms with } \\
\text { valuable OBC programs } \\
\text { (Percentage of all firms } \\
\text { using OBC) }\end{array}$ & $\begin{array}{c}\text { Total } \\
\text { value }^{1)} \\
(\mathrm{DKK} \mathrm{m})\end{array}$ & $\begin{array}{c}\text { Average } \\
\text { value } \\
\text { (DKK m) }\end{array}$ & $\begin{array}{c}\text { Median } \\
\text { value } \\
\text { (DKK m) }\end{array}$ & $\begin{array}{l}\text { Maximum } \\
\text { value } \\
\text { (DKK m) }\end{array}$ \\
\hline 1995 & $0(0 \%)$ & & & & \\
\hline 1996 & $1(17 \%)$ & 5 & 5 & 5 & 5 \\
\hline 1997 & $5(29 \%)$ & 41 & 8 & 8 & 22 \\
\hline 1998 & $33(72 \%)$ & 332 & 10 & 4 & 72 \\
\hline 1999 & $50(76 \%)$ & 1,264 & 25 & 7 & 283 \\
\hline 2000 & $78(80 \%)$ & 3,840 & 49 & 11 & 418 \\
\hline 2001 & $89(83 \%)$ & 3,035 & 34 & 5 & 598 \\
\hline 2002 & $82(87 \%)$ & 1,616 & 20 & 4 & 304 \\
\hline
\end{tabular}

Note to Table 4:

1) All values are at the end of the year. The present exchange rate is $100 \mathrm{DKK}=13.45 \mathrm{EUR}=14.66$ USD.

Table 4 documents that the total value of the programs we have been able to value increased from a mere DKK 5m in 1996 to DKK 3,840m by the end of 2000. Despite numerous new issuances in 2001 and 2002 the total value of the programs dropped to DKK 3 bn by the end of 2001 and further to DKK 1.6 bn by the

\footnotetext{
${ }^{17}$ We note that convertible bond issues have not been included in the valuation.
} 
end of 2002. This was a consequence of a generally negative market development with most underlying stock prices declining considerably during 2001-2002.

It should be emphasized that only a minor part of the increase in the total value of OBC programs up to 2000 is attributable to the fact that the proportion of valuable programs has increased from $17 \%$ in 1996 to more than $80 \%$ in the new millennium. As early as 1998 the proportion of valuable programs was $72 \%$ and it can be reasonably assumed that the figures from that year onwards quite accurately represent the development in the value of $\mathrm{OBC}$. It is seen that the value of $\mathrm{OBC}$ increased about tenfold during the period 1998 to $2000 / 2001$. We conclude that this was partly due to the fact that the number of firms using option-based compensation doubled, but the most important change was in the increase of the average value of the issued programs which nearly quintupled from DKK $10 \mathrm{~m}$ in 1998 to DKK 49m in 2000. A comparison of average value with the median suggests that the distribution of value is characterized by a limited number of very high value programs and a relatively large number of low value programs. The fact that the largest program by the end of 2001 represented a total value of DKK 598m further indicates that this was in fact the case. A closer examination of the end 2000 values of individual programs also shows that 12 firms had programs with a total value of more than DKK $100 \mathrm{~m}$ whereas 7 firms had programs with a value below DKK $1 \mathrm{~m}$. Two years later by the end of 2002 only 4 firms had programs worth more than DKK 100m and 20 had dropped below a value of DKK 1m. The 20 largest end-year option programs in 2000 and 2002 are identified in the bar charts below.

Figure 4. The 20 largest OBC programs at the end of 2000.

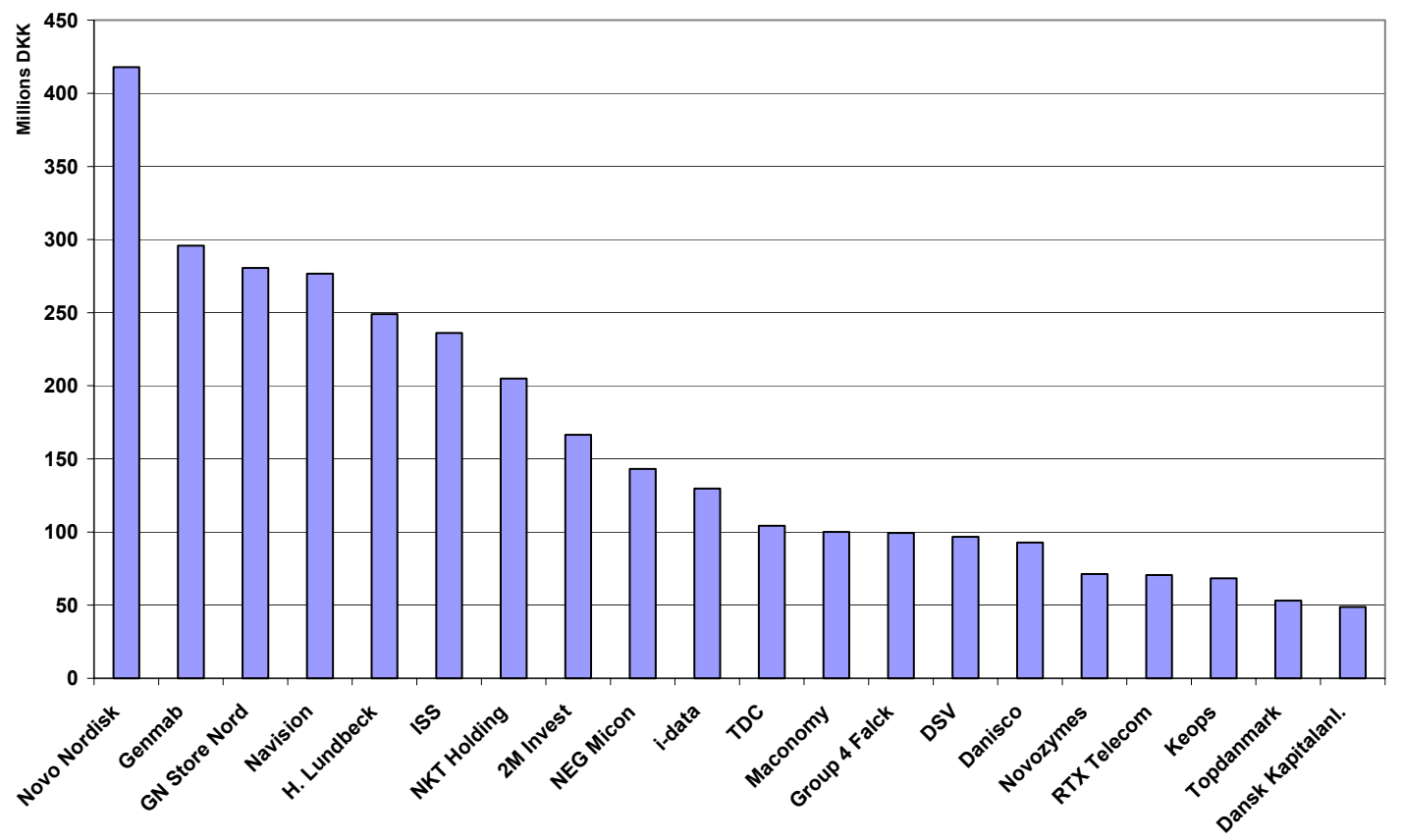


Figure 5. The 20 largest OBC programs at the end of 2002.

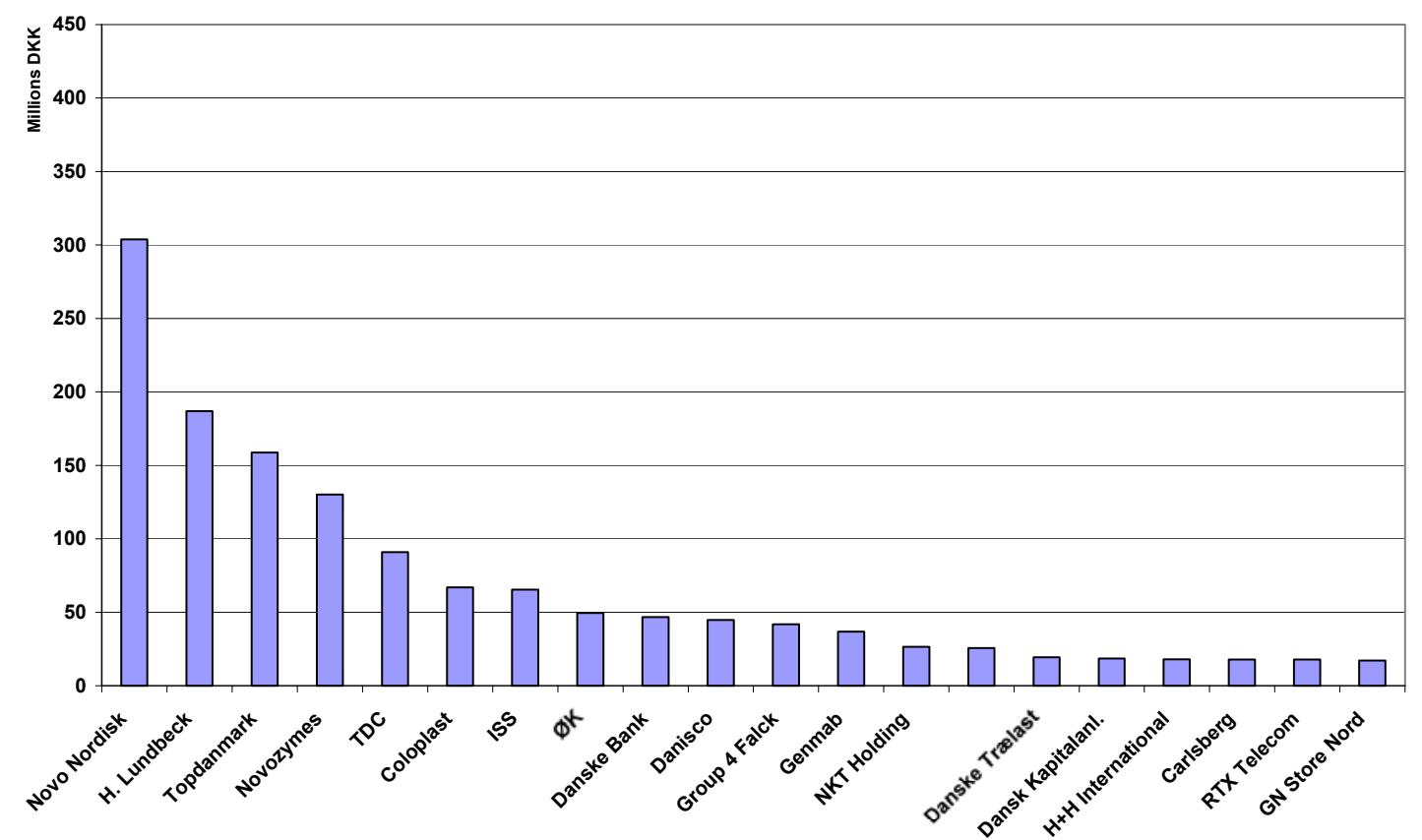

The first noticeable fact from Figures 4 and 5 is that the medical firm Novo has by far the largest option program. This program was worth about DKK $420 \mathrm{~m}$ by the end of 2000 . One year later the value was almost DKK 600m, and by the end of 2002 it had fallen back to a value of DKK $300 \mathrm{~m}$ as seen in Figure 5. The value of Novo's option program represented between $0.46 \%$ and $0.59 \%$ of the market value of Novo's share capital during the period 2000-2002. Another medical firm, relatively small Genmab, held second place in both 2000 and 2001 with an option program worth DKK 300-350m. Genmab subsequently experienced significant adversity when in 2002 the firm's most promising medical project disappointed and had to be dropped. Following the release of this information stock value plummeted $60 \%$ in one day. The drop in stock value caused an estimated drop in option value from DKK $134 \mathrm{~m}$ to DKK $21 \mathrm{~m}-\mathrm{a}$ loss of $84 \%$. However, as can be seen in Figure 5 Genmab still has the $12^{\text {th }}$ largest option program in terms of absolute value by the end of 2002.

An interesting detail revealed in Figure 4 is that the two new economy firms - 2M Invest and I-Data both had their OBC programs on the top ten list for 2000. Both firms later defaulted and were delisted during 2001.

So far we have mainly focused on the absolute value of the OBC programs. However, in an evaluation of the economic significance of the various $\mathrm{OBC}$ programs it would be appropriate to compare the calculated option value to the total underlying stock value in order to gauge relative importance. Some key figures from such analyses are provided in Table 5, which shows the development over time in a number of ratios regarding the relative value of the individual option programs. 
Table 5. Development in the total value of option compensation in listed Danish firms relative to the market value of share capital.

\begin{tabular}{|c|c|c|c|}
\hline & Average & Median & Maximum \\
\hline 1995 & & & \\
\hline 1996 & $0.36 \%$ & $0.36 \%$ & $0.36 \%$ \\
\hline 1997 & $0.63 \%$ & $0.43 \%$ & $1.62 \%$ \\
\hline 1998 & $0.71 \%$ & $0.38 \%$ & $5.72 \%$ \\
\hline 1999 & $0.88 \%$ & $0.57 \%$ & $5.35 \%$ \\
\hline 2000 & $1.99 \%$ & $1.02 \%$ & $18.14 \%$ \\
\hline 2001 & $1.49 \%$ & $0.67 \%$ & $18.30 \%$ \\
\hline 2002 & $1.00 \%$ & $0.59 \%$ & $6.66 \%$ \\
\hline
\end{tabular}

Table 5 shows that when option value is calculated relatively to the market value of the total share capital at firm level, a significant increase occurred up to a peak at the end of 2000. From 1998 to 2000 the average of the relative option values almost tripled from about $0.7 \%$ to about $2 \%$, and the median more than doubled from $0.38 \%$ to approximately $1 \%$. In 2001 and 2002 both absolute and relative option values dropped significantly because of declining underlying asset values and because options are levered instruments. A final interesting observation from Table 5 is that in extreme cases in 2000 and 2001, option values represented nearly $20 \%$ of the market value of the underlying stock.

Figure 6. 20 largest OBC programs by relative value at the end of 2002.

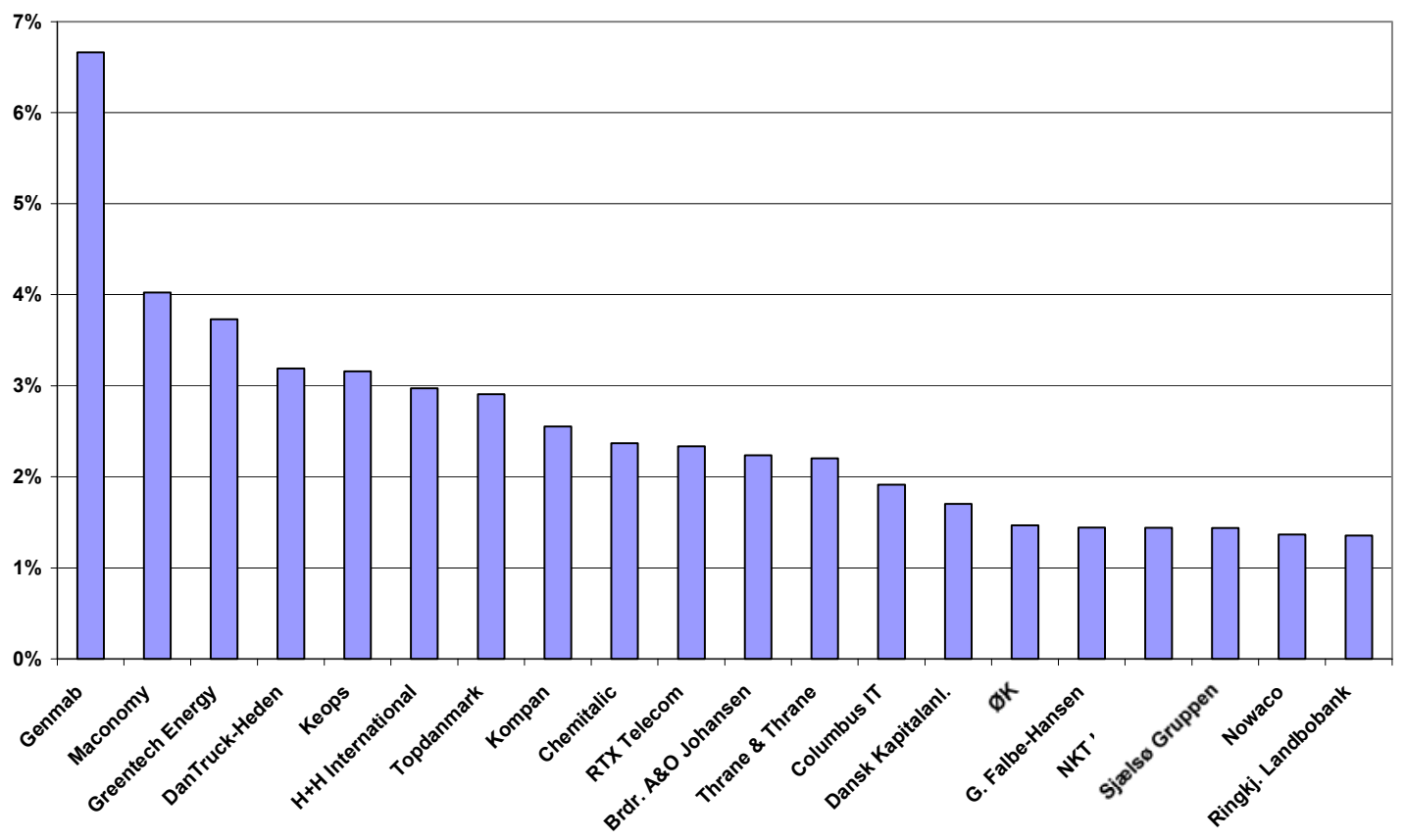


The result from sorting the individual incentive programs according to relative size can be seen in Figure 6 which shows the 20 largest option programs at the end of 2002. As in the previous top 20 list of programs we find firms like Dansk Kapitalanl., Genmab, H+H International, ØK, RTX Telecom, NKT Holding, and Topdanmark whose programs still stand out after taking firm size into account. On the other hand, the option programs of the KFX-firms Carlsberg, Coloplast, Danisco, Danske Bank, DSV, GN Store Nord, Group 4 Falck, H. Lundbeck, ISS, Novo, Novozymes, and TDC no longer emerge among the top 20 group and thus seem relatively moderate despite high absolute values.

Option overhang is another measure often used to assess the use of OBC. A firm's option overhang is defined as the number of issued options relative to the number of shares outstanding and can thus be interpreted as a measure of potential dilution. Some key figures on option overhang are provided in Table 6.

Table 6. Development in option overhang, i.e. the number of issued options relative to the number of shares outstanding in the firm.

\begin{tabular}{|c|c|c|c|}
\hline & Average & \multicolumn{1}{c|}{ Median } & Maximum \\
\hline 1995 & & & \\
\hline 1996 & $2.35 \%$ & $2.35 \%$ & $2.35 \%$ \\
\hline 1997 & $1.61 \%$ & $0.22 \%$ & $5.34 \%$ \\
\hline 1998 & $1.89 \%$ & $1.43 \%$ & $6.74 \%$ \\
\hline 1999 & $2.38 \%$ & $1.77 \%$ & $8.96 \%$ \\
\hline 2000 & $4.18 \%$ & $2.89 \%$ & $20.92 \%$ \\
\hline 2001 & $3.95 \%$ & $3.00 \%$ & $20.92 \%$ \\
\hline 2002 & $3.93 \%$ & $3.19 \%$ & $18.87 \%$ \\
\hline
\end{tabular}

From Table 6 it is seen that average option overhang has increased from 1.61\% in 1997 to around $4 \%$ in 2000-2002. Furthermore, the medians document that many firms have increased the number of options during 2001 and 2002. This constitutes further evidence that the drop in overall value of OBC observed in 2001 and 2002 was primarily due to the drop in stock prices and not due to expiration or exercise of previously issued options. Table 6 also reveals that option overhang in extreme cases is around $20 \%$. In 2002 the record holder is the above-mentioned medical firm, Genmab.

An alternative perspective on the development in the use of option-based compensation may be obtained by considering the year-by-year development in the total value of new issuances. These values have been calculated and a summary is presented in Table 7 below. The table reconfirms the substantial increase in 
the use of OBC and the peak in 2000. Over a period of five years, the total value of newly issued options increased from virtually nothing to more than DKK 2bn in 2000. During 2001 and 2002 both the market and the excitement about using option compensation cooled a little causing the value of new issuances for those years to total about DKK $700-800 \mathrm{~m}$. A similar tendency can be observed for the average crosscompany values, medians and maximum values presented.

Table 7. Development in total value of newly issued option-based compensation by year.

\begin{tabular}{|c|c|c|c|c|c|}
\hline & $\begin{array}{l}\text { Number of } \\
\text { firms with } \\
\text { new valuable } \\
\text { option issues }\end{array}$ & $\begin{array}{l}\text { Total value } \\
\text { (DKK m) }\end{array}$ & $\begin{array}{c}\text { Average } \\
\text { value } \\
\text { (DKK m) }\end{array}$ & $\begin{array}{c}\text { Median } \\
\text { value } \\
\text { (DKK m) }\end{array}$ & $\begin{array}{l}\text { Maximum } \\
\text { value } \\
\text { (DKK m) }\end{array}$ \\
\hline 1995 & 0 & & & & \\
\hline 1996 & 1 & 5 & 5 & 5 & 5 \\
\hline 1997 & 3 & 18 & 6 & 8 & 10 \\
\hline 1998 & 30 & 307 & 10 & 3 & 72 \\
\hline 1999 & 34 & 825 & 24 & 9 & 183 \\
\hline 2000 & 57 & 2,072 & 36 & 11 & 331 \\
\hline 2001 & 54 & 819 & 16 & 3 & 106 \\
\hline 2002 & 53 & 715 & 14 & 4 & 80 \\
\hline
\end{tabular}

So far we have considered the valuation of OBC programs at an aggregated level or at firm level. In the following we will analyze $\mathrm{OBC}$ grants at the personnel level. Since firms must disclose information on the precise distribution of the $\mathrm{OBC}$ on the four personnel groups directors, executives, managers, and other employees we should be able to analyze how the options and their values are distributed among these groups. Unfortunately, the information provided in this respect is often insufficient. One typical problem is that the groups are mixed or that some other classification criteria have been applied instead. In particular, the distribution between managers and other employees is often unclear and details are often omitted from disclosure documents.

In the following analysis we have therefore chosen to distinguish only between directors, executives and employees (managers and other employees). Moreover, the analysis will only include firms providing usable information on the OBC distribution among personnel groups. For the year 2002 for example this means that our basic sample of $94 \mathrm{OBC}$ granting firms is reduced to 79 firms. However, these 79 firms represent $99 \%$ of the total $\mathrm{OBC}$ value, so we find it reasonable to assume that it is possible to assess a 
general pattern in the distribution based on the remaining data set. Table 8 shows the development in the number of firms disclosing information on the distribution of options to the three recipient groups, and it also shows the extent to which firms provide each of the three groups with compensation in the form of options.

Table 8. Development in the distribution (number of firms) of option-based compensation to directors, executives and employees (managers and other employees).

\begin{tabular}{|l|c|r|r|r|}
\hline & $\begin{array}{r}\text { Number of firms with } \\
\text { adequate information }\end{array}$ & Directors & Executives & Employees \\
\hline 1995 & 0 & & & \\
\hline 1996 & 1 & $0(0 \%)$ & $1(100 \%)$ & $1(100 \%)$ \\
\hline 1997 & 4 & $0(0 \%)$ & $4(100 \%)$ & $3(75 \%)$ \\
\hline 1998 & 30 & $4(13 \%)$ & $30(100 \%)$ & $23(77 \%)$ \\
\hline 1999 & 48 & $23(31 \%)$ & $75(100 \%)$ & $64(85 \%)$ \\
\hline 2000 & 75 & $28(33 \%)$ & $85(100 \%)$ & $71(84 \%)$ \\
\hline 2001 & 85 & $26(33 \%)$ & $79(100 \%)$ & $68(86 \%)$ \\
\hline 2002 & 79 & & & \\
\hline
\end{tabular}

Table 8 shows that executives are always included in the OBC programs. This is completely as expected since executives presumably have the largest possibility of affecting the company's stock price via their strategic decisions. The table also shows that more than $80 \%$ of the programs now include the 'employee' group. This indicates that $\mathrm{OBC}$ is not only used to control and focus executive decisions, but also as a means of strengthening employees' incentive to stay with the firm. In any case the result underlines and partly explains the fact that $\mathrm{OBC}$ has been gaining the attention of a wider audience. Perhaps the most interesting finding is the increase in the number and proportion of firms which have included directors in their OBC programs. In about one third of the firms, directors are included in the OBC plans. Interestingly, this contrasts the recommendations in the highly debated government commissioned report on good corporate governance in Denmark, cf. also footnote 1.

Table 9 below is similar to Table 8 except that it shows the development in the distribution of OBC value captured by the individual employee groups. 
Table 9. Development in the distribution (total value) of option-based compensation to directors, executives and employees (managers and other employees).

\begin{tabular}{|l|c|r|r|r|r|}
\hline & $\begin{array}{r}\text { Number of firms with } \\
\text { adequate information }\end{array}$ & $\begin{array}{r}\text { Directors' } \\
\text { Total value } \\
\text { shK m) }\end{array}$ & $\begin{array}{c}\text { Executives' } \\
\text { share of } \\
\text { total value } \\
\text { total value }\end{array}$ & $\begin{array}{c}\text { Employees' } \\
\text { share of } \\
\text { total value }\end{array}$ \\
\hline 1995 & 0 & 5 & $0 \%$ & $18 \%$ & $82 \%$ \\
\hline 1996 & 1 & 41 & $0 \%$ & $45 \%$ & $55 \%$ \\
\hline 1997 & 4 & 324 & $1 \%$ & $51 \%$ & $48 \%$ \\
\hline 1998 & 30 & 1,262 & $2 \%$ & $28 \%$ & $70 \%$ \\
\hline 1999 & 48 & 3,836 & $7 \%$ & $29 \%$ & $65 \%$ \\
\hline 2000 & 75 & 3,033 & $7 \%$ & $26 \%$ & $68 \%$ \\
\hline 2001 & 85 & 1,614 & $4 \%$ & $23 \%$ & $73 \%$ \\
\hline 2002 & 79 & & & & \\
\hline
\end{tabular}

Table 9 shows that over the last four years the executives' share of the total value of outstanding options has been around $25 \%$, whereas employees now hold almost $75 \%$ of the options in terms of market value. It can be seen that directors are also beginning to take their share of option value. Directors' share of option value increased from $0 \%$ to $7 \%$ from the mid 1990 s to 2001 . A share of $7 \%$ of option value seems quite large in light of the modest size of the group of directors in a firm and the increasing practice to include the directors in the group of option recipients has also been widely criticized. The fact that directors cut decreased to $4 \%$ in 2002 is likely a reaction to this criticism.

We conclude the analysis by presenting a couple of tables which compare the development in traditional fixed salary to the value of the total compensation package including options. We focus solely on compensation of directors and executives. The number of employees comprised by these groups as well as their total salaries are typically found in annual reports. Using this information we can calculate salary per director and per executive, both excluding and including OBC. This methodology is the only feasible way of approximating individual salaries as more detailed disclosures on individuals are neither available nor required. 
Table 10. Median salary per director and per executive excluding and including the value of options granted during the year (percentage benefits in the form of options). Numbers are in DKK 1,000.

\begin{tabular}{|c|c|c|c|c|}
\hline Year & \multicolumn{2}{|c|}{ Directors } & \multicolumn{2}{c|}{ Executives } \\
\hline & Excl. & Incl. & Excl. & Incl. \\
\hline 1997 & 79 & $79(+0.0 \%)$ & 1,583 & $1,583(+0.0 \%)$ \\
\hline 1998 & 83 & $86(+2.7 \%)$ & 1,706 & $1,750(+2.6 \%)$ \\
\hline 1999 & 90 & $97(+7.1 \%)$ & 1,897 & $2,302(+21.3 \%)$ \\
\hline 2000 & 111 & $121(+8.6 \%)$ & 2,057 & $2,775(+34.9 \%)$ \\
\hline 2001 & 117 & $129(+10.0 \%)$ & 2,109 & $2,406(+14.0 \%)$ \\
\hline 2002 & 144 & $150(+4.1 \%)$ & 2,212 & $2,592(+17.1 \%)$ \\
\hline
\end{tabular}

Table 11. Average salary per director and per executive excluding and including value of options granted during the year (percentage benefits in the form of options). Numbers are in DKK 1,000.

\begin{tabular}{|c|c|c|c|c|}
\hline Year & \multicolumn{2}{|c|}{ Directors } & \multicolumn{2}{c|}{ Executives } \\
\hline & Excl. & Incl. & Excl. & Incl. \\
\hline 1997 & 96 & $96(+0.0 \%)$ & 1,836 & $1,846(+0.5 \%)$ \\
\hline 1998 & 104 & $114(+10.0 \%)$ & 1,946 & $2,477(+27.3 \%)$ \\
\hline 1999 & 108 & $124(+14.6 \%)$ & 2,183 & $3,049(+39.7 \%)$ \\
\hline 2000 & 123 & $420(+241.6 \%)$ & 2,287 & $6,099(+166.7 \%)$ \\
\hline 2001 & 142 & $213(+50.4 \%)$ & 2,413 & $2,990(+23.9 \%)$ \\
\hline 2002 & 162 & $207(+28.2 \%)$ & 2,528 & $3,130(+23.8 \%)$ \\
\hline
\end{tabular}

Note to Tables 10 and 11: The calculation of median and average salaries is based on the complete data set of firms which have used option compensation from 1997-2002 and which have provided the necessary details for valuation, including details on the distribution of $\mathrm{OBC}$ between directors and executives.

The main conclusion to be drawn from Tables 10 and 11 is that regardless of whether we observe medians or average figures, the introduction of $\mathrm{OBC}$ has not led to a substitution of the traditional fixed salary. Stock options have become a supplement - an extraordinary salary increase. Looking for instance at the median figures regarding the development in compensation to executives in Table 10, we observe that there has been a steady but relatively moderate growth in traditional fixed salary. On top of this, option grants have represented pay rises which totaled a modest $2.6 \%$ in 1998 , but have later increased to two- 
digit percentage figures. A similar development is seen in the median option compensation to directors, but note that when the likely politically motivated modesty with OBC grants to directors took effect during 2002 it led to an unusually large increase in directors' fixed salary. If we observe the average compensation data in Table 11 instead, the benefits represented by options are even more noticeable. Looking at the figures for 2000 , we observe that OBC was by far the largest single element of total compensation for both directors and executives. Murphy (1999) has reported similar findings for the US.

\section{Incentive Effects}

Quantification of the incentives created by OBC contracts is generally very difficult. Most studies of this issue have looked at the sensitivity of option recipients' wealth to changes in key model inputs such as the underlying stock value and asset volatility, see e.g. Jensen and Murphy (1990) and Hall and Liebmann (1998). In the following we concentrate on reporting and discussing deltas and the closely related moneyness for the options in our data set. Delta is the first derivative of the option value with respect to the underlying stock price and it can thus be interpreted as the option holder's (dollar) gain per option from a unit increase in the underlying stock price. The incentive to increase the stock price is therefore stronger the higher the delta. The deltas reported are derived from our Black-Scholes valuation of the OBC contracts. ${ }^{18}$ Moneyness is calculated as the ratio between the market price of the stock and the option's exercise price and is thus a measure of the extent to which the option is in-the-money.

We first provide Table 12 which reports on the options' moneyness and delta at issuance. With median and average moneyness equal to one and slightly above one respectively, the table shows that options are most commonly issued at-the-money. This is again similar to Murphy's (1999) findings for the US. The preference for at-the-money options in the US is largely explained by their relatively favorable treatment in cost accounting. There is no similar favorable treatment of at-the-money options in Denmark. The Danish option design may simply be inspired by/copied from the US market. Another plausible explanation for the popularity of at-the-money option grants is offered by Hall and Murphy (2000) who show that pay-to-performance incentives for risk-averse, undiversified executives are typically maximized by setting exercise prices at (or near) the grant-date market price. As seen from the minimum and maximum moneyness reported in Table 12 there are examples, however, of option programs being issued both out-of-the-money and very deep in-the-money. Similarly, the deltas vary between 0.5 and the maximum theoretical value of one, with typical sensitivities of around 0.75 . Options that are issued deep-

\footnotetext{
${ }^{18}$ The Black-Scholes approach is not ideal when taking the view of the OBC recipient which is the logical and correct view when trying to measure the incentives created. This should be kept in mind when interpreting the results in this section. However, the alternative utility-based approach requires additional and very restrictive assumptions and the uncertainties surrounding $\mathrm{OBC}$ value sensitivities derived from this approach are unlikely to be smaller than the uncertainties surrounding our simpler approach.
} 
in-the-money make little sense as an incentive instrument and suggest the presence of an underlying rentextraction motive. The motive for issuing out-of-the-money or premium priced options may be an attempt to fine tune incentives by making sure that managers are not rewarded until the company's stock price has increased to an acceptable benchmark level.

Table 12. Characteristics of $\mathrm{OBC}$ at issuance. Moneyness is calculated as the ratio between the market price of the stock and the option's exercise price at the time of issuance. Delta is the partial derivative of the Black-Scholes option price with respect to the underlying stock price.

\begin{tabular}{|c|r|r|r|r|}
\hline & Average & Median & Minimum & Maximum \\
\hline Moneyness & 1.12 & 1.00 & 0.39 & 6.40 \\
\hline Delta & 0.74 & 0.73 & 0.53 & 1.00 \\
\hline
\end{tabular}

Table 13 shows the evolution over time in average, median, minimum, and maximum moneyness for the entire sample of outstanding OBC programs. During the period 1998-2000, median moneyness was around one. These numbers are influenced by the facts that during this period each year set a new record in new program issues (see also Table 7) and that these new options were typically granted at-the-money. The influence of the bull market of the late 1990s is better captured by average end-year moneyness which increased from 0.7 in 1996 to 1.32 by the end of 2000. During 2001-2002 average and median moneyness fell back to about 0.65 , as a consequence of the depressed market. The deltas in Table 14 constitute similar evidence.

When comparing the deltas of Tables 12 and 14 it is seen that this contract characteristic can fluctuate significantly as a consequence of movements in the underlying stock value. These deviations occur despite periodic and significant new at-the-money grants. The incentives provided by an entire compensation package is thus quite sensitive to the vagaries of the market and may therefore be difficult to control accurately. 
Table 13. Moneyness of all issued programs. Moneyness is calculated as the ratio between the market price of the stock and the option's exercise price at the end of the year.

\begin{tabular}{|c|r|r|r|r|}
\hline & Average & \multicolumn{1}{c|}{ Median } & Minimum & Maximum \\
\hline 1995 & & & & \\
\hline 1996 & 0.69 & 0.69 & 0.69 & 0.69 \\
\hline 1997 & 0.83 & 0.86 & 0.38 & 1.21 \\
\hline 1998 & 0.96 & 0.96 & 0.42 & 2.31 \\
\hline 1999 & 1.11 & 0.98 & 0.24 & 3.64 \\
\hline 2000 & 1.32 & 1.00 & 0.09 & 5.84 \\
\hline 2001 & 0.93 & 0.79 & 0.03 & 4.36 \\
\hline 2002 & 0.66 & 0.65 & 0.01 & 3.96 \\
\hline
\end{tabular}

Table 14. Delta of all issued programs. Delta is the partial derivative of the Black-Scholes option price with respect to the underlying stock price.

\begin{tabular}{|l|l|l|l|l|}
\hline & Average & Median & Minimum & Maximum \\
\hline 1995 & & & & \\
\hline 1996 & 0.51 & 0.51 & 0.51 & 0.51 \\
\hline 1997 & 0.58 & 0.59 & 0.32 & 0.83 \\
\hline 1998 & 0.62 & 0.67 & 0.22 & 0.95 \\
\hline 1999 & 0.67 & 0.70 & 0.08 & 0.98 \\
\hline 2000 & 0.71 & 0.76 & 0.12 & 0.97 \\
\hline 2001 & 0.58 & 0.59 & 0.03 & 1.00 \\
\hline 2002 & 0.42 & 0.39 & 0.02 & 1.00 \\
\hline
\end{tabular}

\section{Conclusion}

This article has documented that since 1996 there has been a considerable increase in the proportion of Danish listed firms using OBC. The corresponding value of this type of compensation has increased dramatically to peak in 2000 when the total value of issued options reached almost DKK 4bn, or an average program value of approximately DKK 50m. Despite significant new option issuances worth about DKK 700-800m a year, the total value of options fell with the stock market during 2001 and 2002. On 
average the value of stock options represents $1-2 \%$ of the market value of firm stock. Large firms, and especially KFX and KVX firms, use option compensation more frequently than small firms. Firms in the IT, telecom and health care industry are more likely to use option compensation whereas only a few firms in the financial sector make use of option compensation. The massive increase in the use of OBC programs in Danish listed companies is undoubtedly partly due to an increased focus on and awareness of the concepts of shareholder value and corporate governance from the entire Danish business community. Managerial rent seeking (see e.g. Bebchuk, Fried and Walker (2002)) may be another determinant, but testing the causes for and effects of the increased use of OBC in Denmark has been outside the scope of this article. It is obviously an interesting subject for future research.

We have found that the most common type of contract applied in $\mathrm{OBC}$ is a standard call option which is the basic element in about $54 \%$ of all programs. Warrants are used in $27 \%$ of all schemes. The remaining programs combine warrants, options and several other financial instruments. However, the complexities of the programs vary a great deal. On one hand we have fairly transparent programs of standard construction of plain vanilla options or warrants. On the other hand there are quite a few less transparent programs which in some cases include rather complicated constructions and conditions for the instruments applied.

In all cases the option programs issued include executives as recipients. In addition options are issued to the "employee" group in about $85 \%$ of all cases. This group includes managers and other employees. Incentive programs involving options have only recently been extended to include directors. Thus the share of programs involving directors has grown from $0 \%$ in 1998 to $33 \%$ in 2001 . The same pattern is seen when we observe the distribution of program values. By the end of 2001 approximately $7 \%$ of the total option value was held by directors, $26 \%$ by executives, and $68 \%$ by other employees. Directors' share of option value fell back to $4 \%$ in 2002 possibly as a consequence of increased criticism towards granting $\mathrm{OBC}$ to this group. An unusually large increase in directors' (median) fixed salary was simultaneously observed.

The article has also documented how the value of newly issued employee stock options peaked in 2000 with more than DKK 2bn distributed to employees in 57 firms. The newly issued options have generally not replaced traditional salary. Options represent significant extraordinary salary increases on which disclosed information is often highly insufficient. In other words, there is a need for improvement of the amount and quality of information on option compensation in today's market. At present less than $40 \%$ of listed firms fully meet the disclosure requirements outlined in the Rules of the Copenhagen Stock Exchange. 
The results presented in this paper provide the first insight into the application of option-based compensation in Denmark. We hope that this insight, combined with further analyses of the data at hand as well as new information, can help to reveal to which degree option compensation has the desired effect - i.e. whether it motivates employees to make an extra effort which in the end will be measurable in the stock prices for the firms.

\section{References}

Bebchuk, L.A., Fried, J.M. and Walker, D.I. (2002), "Executive Compensation in America: Optimal Contracting or Extraction of Rents?", Harvard University, School of Law Discussion Paper No. 339, to appear in University of Chicago Law Review.

Bechmann, K. L. and P. L. Jørgensen (2002), "Incitamentsprogrammer og oplysningsforpligtelsen (Incentive Schemes and Disclosure Rules)", FINANS/INVEST, No. 1, p. 4-11.

Bechmann, K. L. and P. L. Jørgensen (2003), “Optionsaflønning i danske børsnoterede selskaber (Executive Stock Options in Danish Listed Companies)", Nationaløkonomisk Tidsskrift, 1/2003, p. $68-88$.

Black, F. and M. Scholes (1973), "The Pricing of Options and Corporate Liabilities", Journal of Political Economy, 81(3), 637-654.

Carpenter, J. (1998), "The Exercise and Valuation of Executive Stock Options", Journal of Financial Economics, 48(2), p. 127-158.

Hall, B.J. and J.B. Liebmann (1998), “Are CEOs Really Paid Like Bureaucrats?”, The Quarterly Journal of Economics, 113(3), p. 653-691.

Hall, B.J. and K. J. Murphy (2000), "Optimal Exercise Prices for Executive Stock Options”, American Economic Review, Vol. 90(2), p. 209-214.

Holmstrom, B. (1982), "Moral Hazard in Teams", The Bell Journal of Economics, 13(2), 324340 .

Holmstrom, B. and P. Milgrom (1987), "Aggregation and Linearity in the Provision of Intertemporal Incentives", Econometrica, 55, 303-328. 
Hull, J. C. (2003), Options, futures, and other derivatives, $5^{\text {th }}$ edition, Prentice Hall.

Jensen, M. and W. Meckling (1976), "Theory of the Firm: Managerial Behavior, Agency Costs, and Ownership Structure", Journal of Financial Economics, 3(4), p. 305-360.

Jensen, M. and K. Murphy (1990), "CEO Incentives - It's Not How Much You Pay, But How”, Journal of Applied Corporate Finance, 3(3), p. 36-49.

Jørgensen, P.L. (2002), “American-style Indexed Executive Stock Options”, European Finance Review, 6(3), p. 321-358.

Lambert, R., D. Larcker and R. Verrecchia (1991), "Portfolio Considerations in Valuing Executive Compensation", Journal of Accounting Research, 29(1), p. 129-149.

Merton, R.C. (1976), "Theory of Rational Option Pricing”, Bell Journal of Economics and Management Science, 4, p. 141-183.

Murphy, K. (1999), "Executive Compensation", in O. Ashenfelter and D. Card (eds), Handbook of Labour Economics, Vol. III, North-Holland.

Rappaport, A. (1999), "New Thinking on how to Link Executive Pay with Performance", Harvard Business Review, March-April, p. 91-101.

Rubinstein, M. (1995), "On the Accounting Valuation of Executive Stock Options", The Journal of Derivatives, Fall, p. 8-24. 